\title{
Pharmacokinetic profile of an intradeltoid diclofenac injection in obese Indian volunteers
}

\author{
This article was published in the following Dove Press journal: \\ Journal of Pain Research \\ 18 November 2010 \\ Number of times this article has been viewed
}

\author{
Dhaneshwar Shep' \\ Ashwini Ojha ${ }^{2}$ \\ Sweta Patel ${ }^{3}$ \\ Manish Nivsarkar ${ }^{4}$ \\ Vijaya Jaiswal' \\ Harish Padh ${ }^{5}$ \\ 'Medical Services, Troikaa \\ Pharmaceuticals Ltd., ${ }^{2}$ Department \\ of Bio-analytical, ${ }^{3}$ Department \\ of Biostatistics, ${ }^{4}$ Department of \\ Pharmacology and Toxicology, \\ B.V. Patel Pharmaceutical Education \\ and Research Development Centre, \\ ${ }^{5}$ Director, B.V. Patel PERD Centre, and \\ Project Director, NIPER, Ahmedabad, \\ India
}

Background: A new propylene glycol-free and reduced-volume formulation of diclofenac sodium $75 \mathrm{mg} / \mathrm{mL}$ designed for intradeltoid administration has been found to be bioequivalent to a reference formulation of diclofenac sodium $75 \mathrm{mg} / 3 \mathrm{~mL}$ given via the intragluteal route in normal healthy volunteers. Standard needles may not reach the gluteus maximus muscle in many cases, especially in the obese. The objective of this study was to determine the pharmacokinetic parameters of the new formulation and compare the bioavailability of intradeltoid diclofenac sodium $75 \mathrm{mg} / \mathrm{mL}$ with that of the intragluteal $75 \mathrm{mg} / 3 \mathrm{~mL}$ reference formulation in obese volunteers.

Methods: A comparative, two-way, single-dose, bioavailability study was carried out in 10 obese (body mass index $>25$ ) male Indian volunteers after a washout period of seven days. Blood samples were collected until six hours following drug administration and analyzed using a prevalidated high-pressure liquid chromatography method.

Results: The mean maximum plasma concentration and time to reach maximum plasma concentration for the test formulation were $1.30 \mu \mathrm{g} / \mathrm{mL}$ and 0.50 hours, respectively, versus $0.93 \mu \mathrm{g} /$ $\mathrm{mL}$ and 1.08 hours for the reference formulation. The mean areas under the curve from 0 to last measurable time point $\left(\mathrm{AUC}_{0-\mathrm{t}}\right.$ ) for the test and reference formulations were $2.71 \mu \mathrm{g} \cdot \mathrm{h} / \mathrm{mL}$ and $2.73 \mu \mathrm{g} \cdot \mathrm{h} / \mathrm{mL}$, respectively. The mean AUCs from 0 to infinity $\left(\mathrm{AUC}_{0-\infty}\right)$ for the test and reference formulations were $3.71 \mu \mathrm{g} \cdot \mathrm{h} / \mathrm{mL}$ and $3.75 \mu \mathrm{g} \cdot \mathrm{h} / \mathrm{mL}$, respectively.

Conclusion: The results suggest that the test formulation of diclofenac sodium $75 \mathrm{mg} / \mathrm{mL}$ has an $\mathrm{AUC}_{0-\mathrm{t}}$ and $\mathrm{AUC}_{0-\infty}$ comparable with the reference intragluteal formulation of diclofenac sodium $75 \mathrm{mg} / 3 \mathrm{~mL}$, but with an earlier time to reach maximum plasma concentration and a trend towards a higher maximum plasma concentration. This could be attributed to faster absorption from the deltoid region than from the gluteal region. The test formulation could be helpful in the management of pain in obese or overweight patients and those with dense subcutaneous fat in the gluteal area.

Keywords: bioavailability, diclofenac, intradeltoid, obese, pharmacokinetics

\section{Introduction}

Injectable nonsteroidal anti-inflammatory drugs are commonly used to reduce postoperative pain. They are inexpensive and have been tested over time. They have also been reported to lessen postoperative narcotic requirements and narcotic side effects, including respiratory depression and nausea. ${ }^{1,2}$

Diclofenac sodium injection is effective and well tolerated in the management of postoperative pain ${ }^{1-3}$ and is currently marketed worldwide in a $3 \mathrm{~mL}$ injectable intramuscular formulation. It is generally administered intragluteally. However, the standard needles used may not reach the gluteus maximus muscle in patients who are obese. ${ }^{4-7}$
Medical Services, Troikaa Pharmaceuticals Ltd., Commerce House-I, Satya Marg,

Bodakdev, Ahmedabad 54, India

Tel +91792685624245

Fax +9179268562 4246

Email vijayajaiswal@troikaapharma.com submit your manuscript | www.dovepress.com

Dovepress

DOI: 10.2147 IJPR.SI 3894 
For optimal effect following intramuscular injection it is important that the drug be delivered to the muscle. Problems can arise if drugs designed to be absorbed from muscle are delivered into subcutaneous tissue. Increasing obesity in developed and many developing countries makes this an important concern. ${ }^{7}$ Other injection sites, such as the deltoid, have been suggested and could be more suitable for these patients. The currently available $3 \mathrm{~mL}$ formulation of injectable diclofenac precludes intradeltoid injection due to its larger injection volume.

A new propylene glycol-free and reduced-volume injection of diclofenac sodium has been developed. By using a combination of three classes of solvents containing monohydric and polyhydric alcohols and a polyhydric alcohol ether in combination with water as the principal solvent, it has become possible to dissolve $75 \mathrm{mg}$ of diclofenac in just $1 \mathrm{~mL}$ of injection solution without a substantial increase in viscosity. This new formulation, when administered via the deltoid muscle, was observed to have a bioavailability comparable with the intragluteal formulation of diclofenac sodium $75 \mathrm{mg} / 3 \mathrm{~mL}$ in healthy adult Indian subjects. ${ }^{8}$

The bioavailability of this new formulation has not been defined in obese subjects. The World Health Organization has revised the body mass index (BMI) cutoff for Asian Indians, and suggested a BMI of $25 \mathrm{~kg} / \mathrm{m}^{2}$ to define obesity rather than the $30 \mathrm{~kg} / \mathrm{m}^{2}$ recommended for Europeans. ${ }^{9}$

The objective of the present study was to determine the pharmacokinetics of the new reduced-volume intradeltoid formulation of diclofenac sodium $75 \mathrm{mg} / \mathrm{mL}$ injection and to compare its bioavailability with that of the intragluteal $75 \mathrm{mg} / 3 \mathrm{~mL}$ formulation in adult male Indian subjects with a $\mathrm{BMI}>25$.

\section{Material and methods}

The study was carried out in 10 volunteers with a BMI $>25$ at the B.V. Patel Pharmaceutical Education and Research Development Centre, Ahmedabad, India. All subjects provided written informed consent to participate in the study prior to enrolment, and were free to withdraw at any time during the study. The study was approved by the Institutional Ethics Committee and was conducted in accordance with Good Clinical Practice and the Declaration of Helsinki.

\section{Subjects}

The study population consisted of 10 adult male subjects with a BMI > 25 (mean 26.85, range 25.30-31.16), of mean age 32.3 (25-39) years, mean weight 76.5 (68-89) kg, and mean height $168.7(163-173) \mathrm{cm}$.

\section{Design}

This study was an open-label, randomized, single-dose, two-way, crossover, comparative bioavailability study that assessed the two injectable formulations of diclofenac under fasting conditions, during two separate dosing periods, with a washout period of seven days between the two periods. The volunteers were administered each of the two study drugs after an overnight fast. Dose administration was performed as per the randomization schedule generated at the B.V. Patel Pharmaceutical Education and Research Development Centre, Ahmedabad, India. Subjects received single doses of the intradeltoid test formulation (diclofenac $75 \mathrm{mg} / \mathrm{mL}$, Troikaa Pharmaceuticals Ltd., India) and the intragluteal reference formulation (Voveran ${ }^{\circledR}$, diclofenac $75 \mathrm{mg} / 3 \mathrm{~mL}$, Novartis, India). Intramuscular injections were administered using BD PrecisionGlide needles (Becton Dickinson India Pvt. Ltd., India, $23 \mathrm{G} 0.6 \times 25 \mathrm{~mm}$ ) and BD $2 \mathrm{~mL}$ Discardit II ${ }^{\mathrm{TM}}$ syringes.

\section{Blood sampling}

Following administration of the test/reference formulation in each period, a total of 16 blood samples of $6 \mathrm{~mL}$ each were collected before dosing and at 10, 20, 30, 40, and 50 minutes, and 1.0, 1.5, 2.0, 2.5, 3.0, 3.5, 4.0, 4.5, 5.0, and 6.0 hours following drug administration. During each session, an indwelling catheter was inserted into a forearm vein. Samples were collected in tubes containing lithium heparinate and immediately centrifuged at $4^{\circ} \mathrm{C}$. Plasma was separated and frozen at $-70^{\circ} \mathrm{C}$ until further analysis.

\section{Method of analysis}

After the addition of $0.05 \mathrm{~mL}$ internal standard (mefenamic acid) $25 \mu \mathrm{g} / \mathrm{mL}, 0.5 \mathrm{~mL}$ plasma samples were acidified with $0.05 \mathrm{~mL} 6 \%$ trichloroacetic acid. The drug was extracted into dichloromethane $5 \mathrm{~mL}$. The dichloromethane layer was separated and evaporated under nitrogen gas, and then reconstituted in a $0.1 \mathrm{~mL}$ mobile phase. A $0.06 \mathrm{~mL}$ solution was injected into the column of a high-pressure liquid chromatography system (Jasco 900 series, Japan) equipped with a PU 980 pump, AS 950 autosampler, and UV 975 detector. Separations were achieved using a Grace Vydac $5 \mu \mathrm{m}$ ODS $(4.6 \times 250 \mathrm{~mm})$ column (Separations Group Inc, W.R. Grace \& Co., Columbia, MD, USA) with a mobile phase consisting of acetonitrile and $0.01 \mathrm{M}, \mathrm{pH} 6.6$ potassium dihydrogen orthophosphate buffer (40:60, \% v/v) at a flow rate of $0.8 \mathrm{~mL} / \mathrm{min}$ under ultraviolet detection at $282 \mathrm{~nm}$. The samples were analyzed at $30^{\circ} \mathrm{C}$ with a linear range of $0.1-6 \mu \mathrm{g} / \mathrm{mL}(\mathrm{y}=0.3572 \mathrm{x}+0.0019 ; \mathrm{r}=0.999)$, with an average recovery of $68 \%$. The intraday and between-day 
coefficients of variation $(\% \mathrm{CV})$ of all the quality control samples were $<5 \%$ and $<4 \%$, respectively. The accuracy of the method was between $90 \%$ and $110 \%$. The lowest value on the calibration curve was the lower limit of quantitation, ie, $0.1 \mu \mathrm{g} / \mathrm{mL}$, and the limit of detection was $0.025 \mu \mathrm{g} / \mathrm{mL}$.

\section{Pharmacokinetic analysis}

The pharmacokinetic parameters measured include the observed maximum plasma concentration $\left(\mathrm{C}_{\max }\right)$, time to reach $\mathrm{C}_{\max }\left(\mathrm{T}_{\max }\right)$, and the area under the plasma concentration-time curve from 0 hours to the time point of last measurable concentration $\left(\mathrm{AUC}_{0-\mathrm{t}}\right)$ and 0 hours to infinity $\left(\mathrm{AUC}_{0-\infty}\right)$. The $\mathrm{C}_{\max }$ and $\mathrm{T}_{\max }$ were directly determined from the plasma concentration versus time curves. The $\mathrm{AUC}_{0-\mathrm{t}}$ from time zero to the last quantifiable point $\left(\mathrm{C}_{\mathrm{t}}\right)$ was calculated using the trapezoidal rule, and the extrapolated $\mathrm{AUC}$ from $\mathrm{C}_{\mathrm{t}}$ to infinity $\left(\mathrm{AUC}_{0-\infty}\right)$ was determined as $\mathrm{C}_{\mathrm{t}} / \mathrm{k}_{1}$. $\mathrm{AUC}_{0-\infty}$ was calculated as the sum of the $\mathrm{AUC}_{0-\mathrm{t}}$ plus the ratio of the last measurable concentration to the elimination rate constant $(\mathrm{k})$. Logarithmic transformation was done before data analysis for $\mathrm{C}_{\max }$, $\mathrm{AUC}_{0-t}$, and $\mathrm{AUC}_{0-\infty}$. Analysis of variance (ANOVA) was used to assess effects. Intrasubject variability in terms of the overall \%CV was evaluated from the ANOVA results for $\mathrm{Ln}-$ transformed data. For the pharmacokinetic parameters $\mathrm{C}_{\max }$, $\mathrm{AUC}_{0-t}$, and $\mathrm{AUC}_{0-\infty}, 90 \%$ confidence intervals (CI) for the ratios of test and reference product averages were calculated using ANOVA of the Ln-transformed data. Consistent with the two one-sided tests for bioequivalence, $90 \%$ CIs for the ratio of both the product averages were calculated by first calculating the $90 \% \mathrm{CI}$ for the differences in the averages of the Ln-transformed data and then taking the antilogarithms of the CI obtained.

\section{Safety and tolerability}

General clinical safety was assessed via physical examination and vital signs at screening and at the end of the study. Clinical laboratory tests and electrocardiograms were also conducted at screening, before dosing within each treatment period, and at the end of the study. Adverse events were assessed for severity and relationship to treatment throughout the study.

\section{Results}

\section{Analytic method}

A reverse-phase high-pressure liquid chromatographic method was developed to determine the bioavailability of diclofenac after administration of the two formulations. The calibration range was selected based on expected body concentrations. The method was specific and selective for the analyte, and good linearity was observed within the range. Sufficient recovery was obtained by extraction under acidic conditions in dichloromethane. The precision and accuracy of the method made it suitable for the intended use.

\section{Pharmacokinetic parameters}

The mean plasma concentration-time profiles of diclofenac sodium following administration of single doses to 10 obese volunteers are shown in Figure 1, and a summary of the pharmacokinetic parameters is presented in Table 1. Mean $\mathrm{C}_{\max }$ and mean $\mathrm{T}_{\max }$ for the test formulation were $1.30 \pm 0.18 \mu \mathrm{g} /$ $\mathrm{mL}$ and $0.50 \pm 0.16$ hours, respectively, and $0.93 \pm 0.14 \mu \mathrm{g} /$ $\mathrm{mL}$ and $1.08 \pm 0.31$ hours for the reference formulation. Peak plasma concentrations reported in the literature have ranged from 1.89 to $2.15 \mu \mathrm{g} / \mathrm{mL}$ following an intramuscular injection of diclofenac $75 \mathrm{mg} .{ }^{8,10}$ Variable values of $\mathrm{T}_{\text {max }}$ have been reported, ranging from 3.1 to 6.4 hours for diclofenac sodium with different formulations in healthy subjects. ${ }^{11}$

The mean $\mathrm{AUC}_{0-\mathrm{t}}$ for the test and reference formulations was $2.71 \pm 0.39 \mu \mathrm{g} \cdot \mathrm{h} / \mathrm{mL}$ and $2.73 \pm 0.49 \mu \mathrm{g} \cdot \mathrm{h} / \mathrm{mL}$, respectively. The mean $\mathrm{AUC}_{0-\infty}$ for the test and reference formulations was $3.71 \pm 0.52 \mu \mathrm{g} \cdot \mathrm{h} / \mathrm{mL}$ and $3.75 \pm 0.58 \mu \mathrm{g} \cdot \mathrm{h} / \mathrm{mL}$, respectively. $\mathrm{AUC}_{0-\mathrm{t}}$ and $\mathrm{AUC}_{0-\infty}$ values are in line with those we have reported earlier for healthy volunteers. ${ }^{8}$

The mean elimination rate constant $\mathrm{k}_{\mathrm{el}}$ and mean $\mathrm{t}_{1 / 2}$ for the test and reference formulations were $0.11 \pm 0.02 \mathrm{~h}^{-1}$ and $6.30 \pm 1.27$ hours, and $0.12 \pm 0.02 \mathrm{~h}^{-1}$ and $5.93 \pm 1.11$ hours respectively. The point estimate, $90 \%$ and $95 \% \mathrm{CI}$, and summary of statistics are tabulated in Tables 2 and 3, respectively.

The statistical analysis revealed no significant differences between the test and reference formulations for $\mathrm{C}_{\max }$, $\mathrm{AUC}_{0-\mathrm{t}}$, and $\mathrm{AUC}_{0-\infty}$, suggesting that the pharmacokinetic profile is similar between the two formulations. The $\% \mathrm{CV}$ corresponding to intrasubject variability was $9.18 \%, 5.92 \%$, and $7.95 \%$ for $\mathrm{C}_{\max }, \mathrm{AUC}_{0-\mathrm{t}}$, and $\mathrm{AUC}_{0-\infty}$, respectively. The means $(90 \% \mathrm{CI})$ of the $\mathrm{C}_{\max }, \mathrm{AUC}_{0-\mathrm{t}}$, and $\mathrm{AUC}_{0-\infty}$ for the test:reference ratios were 1.39 (129.8, 151.3), 0.993 (94.6, $104.4)$, and $0.989(92.9,106.08)$, respectively.

\section{Safety and tolerability}

All 10 subjects completed the study, during which there were no premature withdrawals or deaths. No serious adverse events were recorded, and there were no clinically significant changes in vital signs, clinical laboratory variables, electrocardiographic parameters, or physical examination findings during the study. 


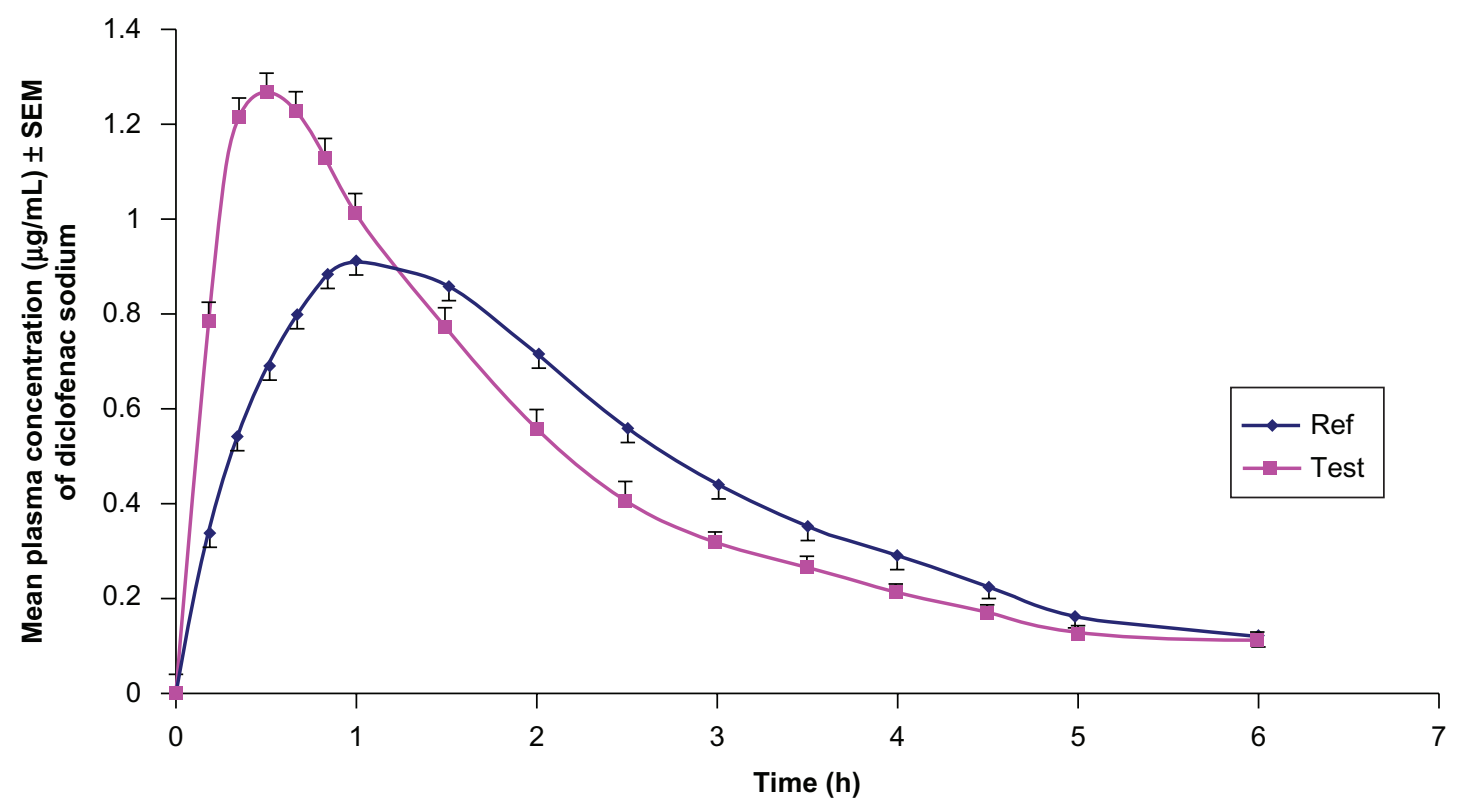

Figure I Linear plot of mean plasma concentrations $(\mu \mathrm{g} / \mathrm{mL})$ versus time profile of diclofenac sodium for test and reference formulations in 10 obese $(\mathrm{BMI}>25)$ male subjects under fasting conditions.

Abbreviations: SEM, standard error of mean; BMI, body mass index.

\section{Discussion}

Depending on the depth of fat, intramuscular injections using standard $35 \mathrm{~mm}$ and $25 \mathrm{~mm}$ needles may be injected subcutaneously in a significant number of patients, and not into the gluteal musculature. This could alter the pharmacokinetics of the administered medication. Hence, an alternative injection site should probably be chosen to increase the success rate of intramuscular deposition of medication. ${ }^{7}$ The deltoid muscle has been suggested as an alternative site for intramuscular drug administration. Several reports have suggested that this is a better site for injection than the gluteal musculature. ${ }^{12,13}$

Based on deltoid fat pad thickness determination, it has been observed that for men weighing $59-118 \mathrm{~kg}$, use of a $25 \mathrm{~mm}$ needle would result in at least $5 \mathrm{~mm}$ of muscle penetration in all subjects. For women weighing less than
$60 \mathrm{~kg}$, a $16 \mathrm{~mm}$ needle would be sufficient to achieve muscle penetration of $5 \mathrm{~mm}$. For women weighing $60-90 \mathrm{~kg}$, a $25 \mathrm{~mm}$ needle would be sufficient, and women weighing more than $90 \mathrm{~kg}$ would require a $38 \mathrm{~mm}$ needle to enable intramuscular administration. ${ }^{14}$ Similar observations were reported by Cook et al, ${ }^{15}$ who suggested that in all males and females with a BMI $<35$, intramuscular injection into the deltoid could be achieved with a $25 \mathrm{~mm}$ needle, whilst in females with a BMI $>35$, a $35 \mathrm{~mm}$ needle is required. Thus, standard needles would reach the muscle in patients by intradeltoid administration.

To address the need for an intradeltoid route to inject diclofenac sodium, a new formulation containing $75 \mathrm{mg} / \mathrm{mL}$ was developed. We have previously reported that the new formulation of injectable intradeltoid diclofenac

Table I Mean pharmacokinetic parameters in 10 obese male volunteers following intragluteal administration of the reference formulation (diclofenac sodium $75 \mathrm{mg} / 3 \mathrm{~mL}$ ) and test formulation (diclofenac sodium $75 \mathrm{mg} / \mathrm{l} \mathrm{mL}$ )

\begin{tabular}{|c|c|c|c|c|c|c|c|c|c|c|c|c|}
\hline \multicolumn{7}{|c|}{ Formulation A (reference) } & \multicolumn{6}{|c|}{ Formulation B (test) } \\
\hline & $\begin{array}{l}C_{\max } \\
(\mu g / m L)\end{array}$ & $\begin{array}{l}T_{\max } \\
\text { (h) }\end{array}$ & $\begin{array}{l}\text { AUC }_{0-\mathrm{t}} \\
(\mu \mathrm{g} \cdot \mathrm{h} / \mathrm{mL})\end{array}$ & $\begin{array}{l}\text { AUC }_{0-\infty} \\
(\mu \mathrm{g} \cdot \mathrm{h} / \mathrm{mL})\end{array}$ & $\begin{array}{l}t_{1 / 2} \\
\text { (h) }\end{array}$ & $\begin{array}{l}k_{\mathrm{el}} \\
\left(\mathbf{h}^{-1}\right)\end{array}$ & $\begin{array}{l}C_{\max } \\
(\mu g / m L)\end{array}$ & $\begin{array}{l}T_{\max } \\
\text { (h) }\end{array}$ & $\begin{array}{l}A U C_{0-t} \\
(\mu g \cdot h / m L)\end{array}$ & $\begin{array}{l}\text { AUC }_{0-\infty} \\
(\mu \mathrm{g} \cdot \mathrm{h} / \mathrm{mL})\end{array}$ & $\begin{array}{l}t_{1 / 2} \\
\text { (h) }\end{array}$ & $\begin{array}{l}k_{\mathrm{el}} \\
\left(\mathbf{h}^{-1}\right)\end{array}$ \\
\hline Mean & 0.93 & 1.08 & 2.73 & 3.75 & 5.93 & 0.12 & 1.30 & 0.50 & 2.71 & 3.71 & 6.30 & 0.11 \\
\hline SD & 0.14 & 0.31 & 0.49 & 0.58 & 1.11 & 0.02 & 0.18 & 0.16 & 0.39 & 0.52 & 1.27 & 0.02 \\
\hline$\% \mathrm{CV}$ & 15.53 & 28.34 & 17.80 & 15.53 & 18.64 & 17.83 & 14.18 & 31.65 & 14.53 & 14.02 & 20.11 & 20.97 \\
\hline
\end{tabular}

Abbreviations: $\mathrm{C}_{\max }$, maximum measured plasma concentration; $\mathrm{T}_{\max }$, time of maximum measured plasma concentration; $A \cup \mathrm{C}_{0-\mathrm{t}}$, area under the plasma concentration versus time curve from time zero to the last measurable concentration; $A \cup C_{0-\infty}$, area under the plasma concentration versus time curve from zero to infinity; $t_{1 / 2}$, time required for the plasma drug concentration to decrease by one-half; $\mathrm{k}_{\mathrm{el}}$, apparent first order elimination or terminal rate constant; SD, standard deviation; \%CV, coefficient of variation. 
Table 2 Point estimate, $90 \%$ and $95 \%$ confidence intervals for the ratio of the product averages of test and reference formulations

\begin{tabular}{|c|c|c|c|c|c|c|}
\hline \multirow[t]{2}{*}{ Parameter } & \multirow{2}{*}{$\begin{array}{l}\text { Point } \\
\text { estimate test: } \\
\text { Reference }\end{array}$} & \multicolumn{2}{|c|}{$\mathbf{9 0} \%$ confidence interval } & \multicolumn{2}{|c|}{$\mathbf{9 5} \%$ confidence interval } & \multirow[t]{2}{*}{$P$ value } \\
\hline & & $\begin{array}{l}\text { Lower confidence } \\
\text { limit }\end{array}$ & $\begin{array}{l}\text { Upper confidence } \\
\text { limit }\end{array}$ & $\begin{array}{l}\text { Lower confidence } \\
\text { limit }\end{array}$ & $\begin{array}{l}\text { Upper confidence } \\
\text { limit }\end{array}$ & \\
\hline$C_{\max }$ & 1.39 & 129.8 & 151.3 & 127.4 & 153.7 & 0.946 \\
\hline $\mathrm{AUC}_{0-\mathrm{t}}$ & 0.993 & 94.6 & 104.4 & 93.5 & 105.7 & 0.135 \\
\hline$A \cup C_{0-\infty}$ & 0.989 & 92.9 & 106.08 & 91.5 & 107.8 & 0.193 \\
\hline
\end{tabular}

Abbreviations: $C_{\max }$, maximum measured plasma concentration; $A \cup C_{0-t}$, area under the plasma concentration versus time curve from time zero to the last measurable concentration; $A \cup C_{0-\infty}$, area under the plasma concentration versus time curve from zero to infinity

$75 \mathrm{mg} / \mathrm{mL}$ is bioequivalent to the intragluteal diclofenac sodium $75 \mathrm{mg} / 3 \mathrm{~mL}$ reference formulation. ${ }^{8}$

All 10 subjects completed the study and were included for both statistical and analytic analysis. Based on repeatedmeasures ANOVA, subject, period, treatment, and interaction term (period $\times$ treatment) showed a nonsignificant difference. The $P$ values suggest that there is no statistically significant difference. The $90 \%$ CIs for all the pharmacokinetic parameters were within bioequivalence acceptance criteria, with the only exception being $\mathrm{C}_{\max }$, for which the upper bound was above the $125 \%$ limit.

With regard to the extent of absorption, the $\mathrm{AUC}_{0-\mathrm{t}}$ and $\mathrm{AUC}_{0-\infty}$ were comparable between the test and reference formulations. Mean $\mathrm{C}_{\max }$ was higher for the test formulation, but this difference was not statistically significant. $T_{\text {max }}$ was earlier for the test formulation than for the reference formulation ( 0.50 hours versus 1.08 hours, respectively). Earlier $\mathrm{T}_{\max }$ and slightly higher $\mathrm{C}_{\max }$ may be attributed to the

Table 3 Summary statistics of diclofenac sodium in 10 obese adult subjects under fasting conditions

\begin{tabular}{|c|c|c|c|c|}
\hline \multirow{2}{*}{$\begin{array}{l}\text { Parameters } \\
\text { summary } \\
\text { statistics }\end{array}$} & \multirow[t]{2}{*}{ Product } & \multirow{2}{*}{$\frac{C_{\max }}{(\mu g / m L)}$} & \multirow{2}{*}{$\frac{A U C_{0-t}}{(\mu g \cdot h / m L)}$} & \multirow{2}{*}{$\frac{\text { AUC }_{0-\infty}}{(\mu \mathrm{g} \cdot \mathrm{h} / \mathrm{mL})}$} \\
\hline & & & & \\
\hline \multirow{2}{*}{ Geometric mean } & Test & 1.29 & 2.68 & 3.68 \\
\hline & Reference & 0.92 & 2.69 & 3.71 \\
\hline \multirow[t]{2}{*}{ LSM } & Test & 1.29 & 2.68 & 3.68 \\
\hline & Reference & 0.92 & 2.69 & 3.71 \\
\hline LSM ratio $\mathrm{B} / \mathrm{A} \%$ & & 140.22 & 99.6 & 99.19 \\
\hline \multicolumn{5}{|c|}{$90 \%$ confidence interval: B/A } \\
\hline Lower limit & & 129.8 & 94.6 & 92.9 \\
\hline Upper limit & & 151.13 & 104.4 & 106.08 \\
\hline \multicolumn{5}{|l|}{$P$ value (ANOVA) } \\
\hline Period & & $>0.05$ & $>0.05$ & $>0.05$ \\
\hline Formulation & & $>0.05$ & $>0.05$ & $>0.05$ \\
\hline Sequence & & $>0.05$ & $>0.05$ & $>0.05$ \\
\hline Intrasubject variabi & tity: \%CV & 9.18 & 5.92 & 7.95 \\
\hline \multicolumn{5}{|c|}{$\begin{array}{l}\text { Abbreviations: } \mathrm{C}_{\max } \text { maximum measured plasma concentration; } \mathrm{AUC}_{0-\mathrm{r}^{\prime}} \text { area } \\
\text { under the plasma concentration versus time curve from time zero to the last } \\
\text { measurable concentration; } \mathrm{AUC} \mathrm{C}_{0-\infty} \text {, area under the plasma concentration verses } \\
\text { time curve from zero to infinity; LSM, least squares mean; } \mathrm{A} \text {, reference product; } \\
\mathrm{B} \text {, test product; ANOVA, analysis of variance; } \mathrm{B} / \mathrm{A} \text {, bioavailability ratio test (B)/ } \\
\text { Reference (A); \%CV, coefficient of variation. }\end{array}$} \\
\hline
\end{tabular}

depth of subcutaneous fat in the gluteal region and better blood flow to the deltoid than to the gluteus muscle. ${ }^{16}$

Diclofenac has been reported to be associated with gastrointestinal, cardiovascular, and hepatic side effects. ${ }^{17}$ The most common side effects following diclofenac injection are gastrointestinal and pain at site of injection. ${ }^{18}$ Mild to moderate adverse events have been reported in about $5 \%$ patients with renal colic following intramuscular diclofenac. ${ }^{19}$ Only minor gastrointestinal side effects have been reported following intramuscular diclofenac postoperatively. ${ }^{20}$ In the present study, both formulations were well tolerated, and no adverse events were reported.

\section{Conclusion}

Our results suggest that the test formulation of diclofenac sodium $75 \mathrm{mg} / \mathrm{mL}$ has a comparable $\mathrm{AUC}_{0-\mathrm{t}}$ and $\mathrm{AUC}_{0-\infty}$ but an earlier $\mathrm{T}_{\max }$ and a trend towards a higher $\mathrm{C}_{\text {max }}$ in comparison with the reference diclofenac sodium $75 \mathrm{mg} / 3 \mathrm{~mL}$ formulation. This could be attributed to faster absorption from the deltoid region than from the gluteal region. The test formulation, which can be given by the intradeltoid route using standard needles, would be helpful in the management of postoperative pain and other painful conditions. This formulation would be especially useful in obese or overweight patients and those with dense subcutaneous fat in the gluteal region, in whom intramuscular injections into the gluteus musculature using standard needles may fail to reach the muscle.

\section{Acknowledgments}

We are grateful to Troikaa Pharmaceuticals Ltd., Ahmedabad, India, for providing the drug samples, and to Ms Rita Rana and the clinical staff of B.V. Patel Pharmaceutical Education and Research Development Centre, Ahmedabad, India, for their assistance with the pharmacokinetic study.

\section{Disclosure}

The authors report no conflicts of interest in this work. 


\section{References}

1. Bourlert A. Diclofenac intramuscular single dose to decrease pain in post operative Caesarean section: A double blind randomized controlled trial. J Med Assoc Thai. 2005;88(1):15-19.

2. Al-Waili NS. Efficacy and safety of repeated postoperative administration of intramuscular diclofenac sodium in the treatment of post-cesarean section pain: A double-blind study. Arch Med Res. 2001;32(2):148-154.

3. Rautoma P, Santanen U, Luurila H, et al. Preoperative diclofenac is a useful adjunct to spinal anesthesia for day-case varicose vein repair. Can J Anesth. 2001;48(7):661-664.

4. Zaybak A, Güneş UY, Tamsel S, et al. Does obesity prevent the needle from reaching muscle in intramuscular injections? J Adv Nurs. 2007;58(6):552-556.

5. Chan VO, Colville J, Persaud T. Intramuscular injections into the buttocks: Are they truly intramuscular? Eur J Radiol. 2006;58(3):480-484.

6. Nisbet AC. Intramuscular gluteal injections in the increasingly obese population: Retrospective study. BMJ. 2006;332(7542):637-638.

7. Burbridge BE. Computed tomographic measurement of gluteal subcutaneous fat thickness in reference to failure of gluteal intramuscular injections. Can Assoc Radiol J. 2007;58(2):72-75.

8. Ojha A, Shep D, Nivsarkar M, Patel S, Jaiswal V, Padh H. Pharmacokinetic profile of a new formulation of injection diclofenac designed for intradeltoid use. Expert Opin Pharmacother. 2009;10(4):517-522.

9. The Asia Pacific perspective: Redefining obesity and its treatment. Regional Office for the Western Pacific of the World Health Organization. World Health Organization, International Association for the Study of Obesity and International Obesity Task Force. St Leonards, Australia: Health Communications Australia Pty Limited; 2000.

10. Kurowski M. Pharmacokinetics and biological availability of diclofenac preparations following intramuscular injection of $75 \mathrm{mg}$ and oral administration of $150 \mathrm{mg}$ of active drug. Z Rheumatol. 1988;47(1):37-42.
11. Nawaz R, Nawaz M, Butt A, Zafar M, Saleemi U. Kinetics of diclofenac sodium; single oral dose disposition in male volunteers. The Professional. 2004;11(4):411-416.

12. Grabinski PY, Kaiko RF, Rogers AG, Houde RW. Plasma levels and analgesia following deltoid and gluteal injections of methadone and morphine. J Clin Pharmacol. 1983;23(1):48-55.

13. Saxena A, Grace J, Josie L. Risperidone long-acting injections: Successful alternative deltoid muscle injections for refractory schizophenia. J Psychiatry. 2008;5(9):40-42.

14. Poland GA, Borrud A, Jacobson RM, et al. Determination of deltoid fat pad thickness. Implications for needle length in adult immunization. JAMA. 1997;277(21):1709-1711.

15. Cook IF, Williamson M, Pond D. Definition of needle length required for intramuscular deltoid injection in elderly adults: An ultrasonographic study. Vaccine. 2006;24(7):937-940.

16. Evans EF, Proctor JD, Fratkin MJ, Velandia J, Wasserman AJ. Blood flow in muscle groups and drug absorption. Clin Pharmacol Ther. 1975;17(1):44-47.

17. Aithal GP, Day CP. Nonsteroidal anti-inflammatory drug-induced hepatotoxicity. Clin Liver Dis. 2007;11(3):563-575.

18. Prabhakar H, Shirao SA, Shelgaonkar VC, et al. Comparative evaluation of intramuscular ketoprofen and diclofenac sodium for post-operative pain relief. Internet Journal of Anesthesiology. 2006;11(1).

19. Fraga A, Moreira-da-Silva V, Severo L, et al. Intramuscular etofenamate versus diclofenac in the relief of renal colic: A randomised, single-blind, comparative study. Clin Drug Investig. 2003;23(11):701-706.

20. Hynes D, McCarroll M, Hiesse-Provost O. Analgesic efficacy of parenteral paracetamol (propacetamol) and diclofenac in postoperative orthopaedic pain. Acta Anaesthesiol Scand. 2006;50(3): 374-381.
Journal of Pain Research

\section{Publish your work in this journal}

The Journal of Pain Research is an international, peer-reviewed, open access, online journal that welcomes laboratory and clinical findings in the fields of pain research and the prevention and management of pain. Original research, reviews, symposium reports, hypothesis formation and commentaries are all considered for publication.

\section{Dovepress}

The manuscript management system is completely online and includes a very quick and fair peer-review system, which is all easy to use. Visit http://www.dovepress.com/testimonials.php to read real quotes from published authors. 